\title{
HISTÓRIAS EM QUADRINHOS: IMAGEM E TEXTO EM TRADUÇÃO
}

\author{
Sabrina Moura Aragão ${ }^{1}$ e Adriana Zavaglia ${ }^{2}$
}

\begin{abstract}
RESUMO: Ao se considerar as histórias em quadrinhos como uma linguagem que opera com imagem e texto, observa-se que o trabalho do tradutor não se limita apenas à decifração de uma língua e cultura estrangeiras; ao contrário, percebe-se a existência de uma relação de interdependência entre esses dois tipos de linguagem, o que cria diversos efeitos estilísticos, aproximando-se, com frequência, da fala cotidiana. Além disso, está implícita nessa relação interdependente a fluência de leitura, que depende, em grande parte, da naturalidade com que são interpretados texto e imagem na língua de chegada. Partindo disso, o presente artigo busca analisar, do ponto de vista verbal e não-verbal, as relações entre imagem e texto em tradução de quadrinhos, focalizando questões que envolvem o estudo das estratégias utilizadas pelos tradutores brasileiros na tradução para o português da série francesa Astérix.
\end{abstract}

PALAVRAS-CHAVE: Histórias em quadrinhos; Imagem; Texto; Tradução.

ABSTRACT: Considering comics as a language which deals with image and text, it is observed that the translator's work

1 Mestranda junto à Área de Estudos Linguísticos, Literários e Tradutológicos em Francês da Faculdade de Filosofia, Letras e Ciências Humanas (FFLCH) - Universidade de São Paulo.

2 Prof ${ }^{a}$. Dra da Área de Estudos Linguísticos, Literários e Tradutológicos em Francês da FFFLCH, USP.

TradTerm, 16, 2010, p. 435-463 
is not limited to decipher a foreign language and culture, but rather one can perceive the existence of a relationship of interdependence between these two types of language, which creates various effects and stylistic approaches, often of everyday speech. Moreover, it is implicit in this interdependent relationship the reading fluency, which depends in large part to the ease with which people interpret text and image in the target language. With this starting point, this article examines, in terms of verbal and nonverbal, the relationship between image and text in comics translation, focusing on issues involving the study of strategies used by translators in the Brazilian translation of the Asterix French series into Portuguese.

KEYWORDS: Comics; Image; Text; Translation.

\section{Introdução}

As histórias em quadrinhos (HQ) têm gozado de grande difusão no mundo todo, com um público leitor heterogêneo. No cenário brasileiro, também é considerável a entrada e o consumo de quadrinhos importados que tratam de temas e assuntos variados, desde Maus, de Art Spiegelman, que retrata o Holocausto, até o humor erótico de Robert Crumb, em Fritz, the Cat. Vale ressaltar também a recente onda de quadrinhos orientais, que invadiu as bancas e livrarias não só do Brasil, como dos Estados Unidos e Europa.

Ocorre que o sucesso e o alcance dessa forma de linguagem no cenário mundial dependem da tradução, cujo volume notável - é um fenômeno visível em diversos países. Entretanto, o estudo específico da tradução de histórias em quadrinhos, que vem se desenvolvendo gradativamente, ainda não é substancial, tanto no âmbito das Ciências da Linguagem como no dos Estudos da Tradução. A pouca ênfase dada a esse tipo de pesquisa está ligada, em grande parte, a uma série de estereótipos atribuídos a essa forma de mídia, que, muitas vezes, é vista como literatura menor. No entanto, é justamente a conjugação da imagem e do texto em sua configuração, aliada ao grande número e

TradTerm, 16, 2010, p. 435-463 
à heterogeneidade de publicações na área, que tornam as histórias em quadrinhos um material valioso para a investigação científica.

Nesse sentido, o presente artigo busca trazer uma contribuição para o estudo específico da tradução de HQ, propondo reflexões e possibilidades de análise dessa forma de expressão tão popular e ainda tão pouco explorada nos Estudos da Tradução. Para tanto, apresentaremos uma tipologia das relações entre imagem e texto na tradução de histórias em quadrinhos.

\section{A imagem e o texto nas histórias em quadrinhos}

Segundo Wolk (2007), as HQ constituem-se um bem cultural que vem ganhando cada vez mais espaço no mercado editorial, haja vista a sofisticação de suas publicações mais recentes, além de conquistar status de obra de arte. Nesse sentido, é possivel, para o autor, observar uma evolução dessa forma de expressão que anteriormente era vista, na qualidade de produto dirigido ao público infantil, como algo sem grandes pretensões estilísticas. Hoje, porém, os quadrinhos representam uma linguagem tão complexa que podem ser até mesmo equiparados à literatura e, entre outros, ao cinema, tanto do ponto de vista estético e estilístico quanto do tratamento que as editoras e a mídia de uma forma geral lhes têm dado: de panfletos periódicos, muitas vezes publicados marginalmente em jornais, a edições bem acabadas e luxuosas com direito a um lugar de destaque nas estantes das grandes livrarias.

Assim como outras formas de expressão, as histórias em quadrinhos lidam com a subjetividade da percepção e da interpretação; desse modo, autores e leitores muitas vezes interpretam de formas diferentes aquilo que ali é representado, sem necessariamente haver coincidências. Elementos culturais e ideológicos, então, podem ser identificados diversamente, ainda mais quando um determinado quadrinho é inserido, pela tradução, em um outro país. A esse respeito, ao discutir a subjetividade da percepção no âmbito das histórias em quadrinhos, Wolk (2007) declara que:

TradTerm, 16, 2010, p. 435-463 
quadrinhos são, inevitavelmente, uma metáfora para a subjetividade da percepção. Duas pessoas não experimentam o mundo da mesma maneira, dois cartunistas não o desenham da mesma maneira e a forma como eles o desenham é o mais próximo que um leitor pode experimentálo, através dos olhos deles. ${ }^{3}$ (Wolk, 2007:21, tradução nossa)

Para Wolk (2007), portanto, como não se "experimenta o mundo" da mesma maneira, não se lê quadrinhos do mesmo modo, tanto em seus contextos originais, ou seja, autor, ilustrador e leitores da língua e da cultura de origem, quanto em contextos de tradução, nos quais estão implicadas ao menos duas línguas e culturas, que percebem a relação complexa entre texto e imagem de modos distintos. Sobre essa complexidade, Eisner (2005) afirma:

Nos quadrinhos, ninguém realmente sabe dizer ao certo se as palavras são lidas antes ou depois de se ver a imagem. Não temos evidência real de que elas são lidas simultaneamente. Existe um processo diferente de conhecimento entre ler palavras e imagens. Mas, em qualquer caso, a imagem e o diálogo dão significado um ao outro um elemento vital na narrativa gráfica. (Eisner, 2005:63)

Como se pode observar, Eisner, criador da renomada série The Spirit, assevera a importância dessa relação no desenvolvimento da narrativa das HQ, dando especial ênfase à relação de complementaridade semântica entre palavras e imagens. Essa interdependência configura, como em outras formas de mídia, a natureza das HQ, que são sistemas sincréticos, ou seja, "acionam várias linguagens de manifestação" (Greimas \& Courtés apud Pietroforte, 2007:11). Isso quer dizer que uma mesma representação semântica pode manifestar-se por meio de planos de ex-

3 "cartooning is, inescapably, a metaphor for the subjectivity of perception. No two people experience the world the same way; no two cartoonists draw it the same way, and the way they draw it is the closest a reader can come to experiencing it through their eyes."

TradTerm, 16, 2010, p. 435-463 
pressão de ordens diferentes, tais como pela junção dos planos verbal e não-verbal. Desse modo, como sistema heterogêneo, justamente por fazerem uso de diferentes códigos simultaneamente, as histórias em quadrinhos têm a imagem como elemento constituinte - visivel e construído - da narrativa. ${ }^{4}$

No entanto, mesmo considerando as HQs como "um sistema de dependências internas (imagem/texto, imagem/imagem, etc.)", Fresnault-Deruelle (1972:19, tradução nossa) atribui maior importância ao texto que à imagem, pois considera que as ilustrações funcionam como cenários para as ações ou como representações da realidade, nos quais os textos se inserem para explicar ou "combater a polissemia". Para tanto, evoca as ideias de Roland Barthes (1990) a respeito da função de fixação que o texto desempenha quando associado à imagem, pois "a fixação é um controle, detém uma responsabilidade sobre o uso da mensagem, frente ao poder de projeção das ilustrações" (Barthes, 1990:33).

Porém, além da função de fixação, Barthes (1990) descreve ainda outra, a de relais, que estabelece uma relação de complementaridade com a imagem. Afirma o autor:

A fixação é a função da mensagem lingüística; é comumente encontrada na fotografia jornalística e na publicidade. A função de relais é mais rara (pelo menos no que concerne à imagem fixa); vamos encontrá-la sobretudo nas charges e nas histórias em quadrinhos. Aqui a palavra (na maioria das vezes um trecho de diálogo) e a imagem têm uma relação de complementaridade; as palavras são, então, fragmentos de um sistema mais geral, assim como as imagens, e a unidade da mensagem é feita em um nivel superior: o da história, o da anedota, o da diegese. (Barthes, 1990:33-34, grifos nossos)

Mesmo que Barthes (1990) tenha associado o relais às HQs e a fixação à fotografia e à publicidade, Fresnault-Deruelle (1972)

4 Cabe aqui notar que outras manifestações, como os textos literários, ao contrário das HQ, trabalham no plano verbal com um espaço de interpretação de imagens não visiveis a priori, que deverá ser construído pelo leitor a partir das palavras. Sobre a relação entre imagem e texto em obras literárias ilustradas, vale conferir o trabalho de Pereira (2008).

TradTerm, 16, 2010, p. 435-463 
estabeleceu, a partir desses conceitos, uma relação entre a fotografia e o desenho, uma vez que, para ele, ambos são uma forma de representar a realidade. Contudo, a nosso ver, o autor, ao fazer essa aproximação, desconsidera outras construções que privilegiam muito mais a interpretação de sentidos do que a identificação de significados numa imagem. Assim, a imagem não se limita a uma função mimética como a fotografia jornalística, pois não só representa espaços e caracteriza personagens, como também goza do potencial de subverter essa função graças ao gênio do autor.

Nessa mesma direção, Cagnin (1975) afirma:

O desenho difere da fotografia justamente na procura destes elementos colocados intencionalmente no quadro. $\mathrm{O}$ fotógrafo apresenta o que conseguiu captar com um instrumento mecânico. O desenhista conhece uma porção de normas e recursos estéticos (o código icônico) e na composição do seu desenho procura conscientemente transmitir certos efeitos colaterais, além do significado literal da sua imagem e da história contada. (Cagnin, 1975:97)

Como se percebe, os processos que envolvem a composição de um desenho e a captação de uma imagem por meio da fotografia se diferenciam essencialmente em função do que o desenhista e o fotógrafo são capazes de realizar com a imagem representada. Assim, a relação que se estabelece entre imagem e texto manifesta-se diferentemente em mídias distintas.

Para nós, portanto, as relações entre imagem e texto nas HQs, ao contrário do que diz Fresnault-Deruelle (1975), não se limitam a representar cenários que se explicam ou contextualizam através do texto. Pelo contrário: o trabalho estético que aí se observa visa a criar novos efeitos que ultrapassam a simples representação da realidade, o que encaixaria esse tipo de relação no conceito de relais anteriormente citado, graças às novas relações que o texto estabelece com a imagem a fim de causar o efeito cômico por meio de jogos de palavras, trocadilhos, entre outros. 


\section{A tradução de histórias em quadrinhos}

Segundo Souza (1997), o humor nas histórias em quadrinhos é construído a partir de elementos tanto visuais como linguísticos. Assim, a tradução de histórias em quadrinhos em pauta neste artigo, encaixando-se no gênero humorístico, como é o caso de Asterix, exige uma série de estratégias que busquem recriar, na língua de chegada, os efeitos de humor presentes na língua de partida, considerando não só o texto, como também a imagem.

Ainda segundo Souza (1997), o grande problema das traduções de gêneros humorísticos é a falta de naturalidade nos contextos da língua de chegada, pois muitas vezes o humor é construído a partir da desconstrução de valores culturais e linguísticos próprios do contexto da língua e da cultura de partida. Esses problemas são reforçados pela presença da imagem, que muitas vezes limita as possibilidades de tradução e, diferentemente do texto, com frequência não pode ser manipulada pelo tradutor. ${ }^{5}$

Nesse sentido, a tradução que lida com a relação entre a imagem e o texto na construção de efeitos de humor se coloca como uma atividade extremamente complexa, pois "o texto remete à própria imagem, [que, por sua vez,] fornece o contexto para sua compreensão. O efeito cômico é obtido a partir da interação estabelecida entre esses dois sistemas gráficos" (Souza, 1997:45).

Ora, na tentativa de estabelecer uma aproximação com a fala cotidiana, os autores da série Asterix representam vários gestos. Estes fazem parte dos contextos comunicativos da língua francesa, os quais, na qualidade de representação mimética da realidade, são interpretados pelo leitor francófono sem dificuldades. Tal interpretação só é possivel graças aos conheci-

5 De acordo com a lei de direitos autorais (Lei $\mathrm{n}^{\circ}$ 9.610/98), o autor de qualquer obra artística, seja ela textual ou visual, tem o direito de autorizar como sua obra será utilizada ou veiculada. No caso das histórias em quadrinhos, os direitos autorais de tradução frequentemente não incluem os direitos sobre a imagem, que, nesse caso, não pode ser modificada.

TradTerm, 16, 2010, p. 435-463 
mentos de mundo partilhados pelo emissor e o receptor da mensagem, o que, para ter êxito na tradução, dependerá do trabalho do tradutor.

A esse respeito, vale citar Cagnin (1975), que discorre sobre os contextos e a sua relação com os conhecimentos partilhados entre leitor e autor de histórias em quadrinhos. Segundo o estudioso, "o leitor recebe a mensagem na medida em que percebe a representação dada e consegue fazer diversos relacionamentos" (Cagnin, 1975:46). Nessa direção, o autor elabora a seguinte classificação para a forma pela qual os contextos se apresentam nas histórias em quadrinhos:

1. Contexto intraicônico: relação entre diferentes elementos da imagem.

2. Contexto intericônico: relação entre as imagens associadas em série ou sucessão (sequência).

3. Contexto extraicônico: a imagem associada a elementos de natureza diversa (tempo, idade, instrução, sociedade, cultura, ambiente em que se dá a comunicação); poderia este contexto ser particularizado em:

- contexto situacional, que congrega o conjunto de elementos comuns ao emissor e ao receptor no ato da comunicação;

- contexto global, mais amplo, em que são colocadas todas as implicações culturais e espaço-temporais (impossiveis de delimitar, dada a imensa diversidade entre as pessoas). (Cagnin, 1985:46)

Dentre essas classificações, interessa-nos a que menciona o contexto extraicônico, o qual se relaciona com questões culturais próprias de cada país expressas de forma bastante recorrente nas $\mathrm{HQ}$, posto que "elementos comuns ao emissor e ao receptor" são um pressuposto para a compreensão da mensagem dos quadrinhos, mensagem esta formada pela relação entre a imagem e o texto. Considerando, especificamente, a relação entre emissor, receptor e mensagem, Aubert (1994) elabora o seguinte esquema para o ato tradutório:

TradTerm, 16, 2010, p. 435-463 
MENSAGEM 1

MENSAGEM 2

Emissor $1 \rightarrow$ Receptor $1 \rightarrow$ BLOQUEIO $\rightarrow$ Emissor $2 \rightarrow$ Receptor 2

Levando em conta as questões aqui levantadas, podemos inserir os participantes do ato tradutório no esquema acima da seguinte maneira:

$\begin{array}{lllll}\text { MENSAGEM } 1 & \text { MENSAGEM } 2 \\ \text { Emissor } 1 \rightarrow \text { Receptor } 1 \rightarrow & \text { BLOQUEIO } \rightarrow & \text { Emissor } 2 \rightarrow \text { Receptor } 2 \\ \text { (Autor) } & \text { (Leitor francófono) } & \text { (Tradução) } & \text { (Tradutor) } & \text { (Leitor brasileiro) }\end{array}$

Nesse esquema, o Emissor 1 e o Receptor 1 partilham dos mesmos códigos (língua francesa) e estão inseridos no mesmo ambiente sociocultural, possibilitando a compreensão da Mensagem 1. Ao se tentar recriar a Mensagem 1 para um novo contexto sociocultural, com códigos diferentes, ocorre o Bloqueio, que pode ser superado através da tradução. Assim, o Emissor 2, presumivelmente dominando os códigos da Mensagem 1, transmite ao Receptor 2 a Mensagem 2, que, em tese, corresponde à Mensagem 1. Então, estabelece-se por meio do processo de tradução, "uma segunda relação comunicativa" (Aubert, 1994:10), na qual manifestam-se contextos diferentes, novos códigos, novas relações socioculturais e outras formas de visão de mundo.

No caso da tradução de histórias em quadrinhos, além do bloqueio linguístico apontado por Aubert (1994), configura-se um outro parâmetro: a imagem. Assim, o tradutor necessita dar conta não só das diferenças que surgem do contato interlinguístico, mas também das imagens que representam elementos muitas vezes estranhos ao ambiente cultural do leitor da tradução, principalmente quando os efeitos de sentido gerados se dão na conjunção entre texto e imagem.

Observe-se a Figura 1 a seguir:

TradTerm, 16, 2010, p. 435-463 


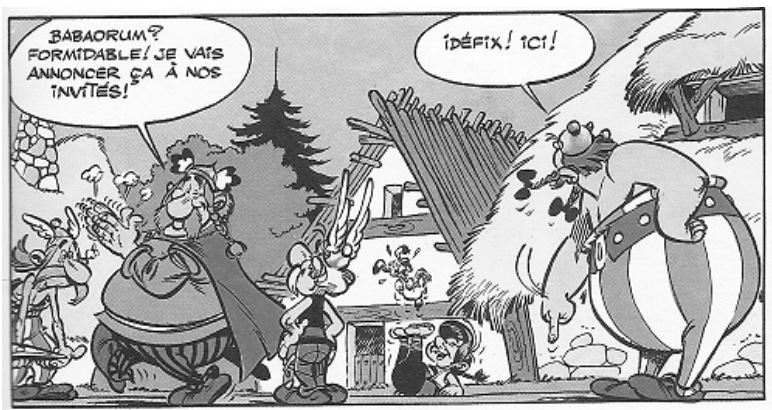

$1^{\circ}$ Balão: Babaorum?

Formidável! Vou dar a boa

notícia aos convidados!

$2^{\circ}$ Balão: Idéiafix! Já para cá!

(Tradução apresentada na edição brasileira de Astérix en Corse)

Figura 1: Extraído de UDERZO, A. \& GOSCINNY, R. Astérix en Corse. Paris: Hachette, 2005

No caso acima, observam-se dois gestos: o do chefe, que esfrega as mãos indicando contentamento, e o de Obelix, que designa uma ordem. O gesto do chefe acompanha especialmente a sequência interjectiva "Formidable!" /"Formidável!", que dialoga com os outros elementos textuais e com o contexto anterior, já apresentado ao leitor. O gesto de Obelix, por sua vez, relaciona-se mais diretamente a "Ici!"/"Aqui!", posterior a um chamamento. Tais relações entre imagem e texto representam mimeticamente contextos reais de comunicação, ao mesmo tempo em que evocam conhecimentos de mundo, os quais necessitam ser compartilhados com o leitor. Na figura 1, como se vê, as relações evocadas são identificáveis tanto no contexto de partida (França) como no contexto de chegada (Brasil) por seus leitores possiveis (o do original ou o da tradução). Tais relações, justamente, esses leitores são capazes de reconstruir sem ruídos.

No entanto, muitas vezes a relação entre imagem e texto nas histórias em quadrinhos se manifesta por trocadilhos e jogos de palavras que, reforçados pela imagem, provocam efeitos inusitados e criativos. Um exemplo desse tipo de composição pode ser observado na Figura 2 a seguir: 


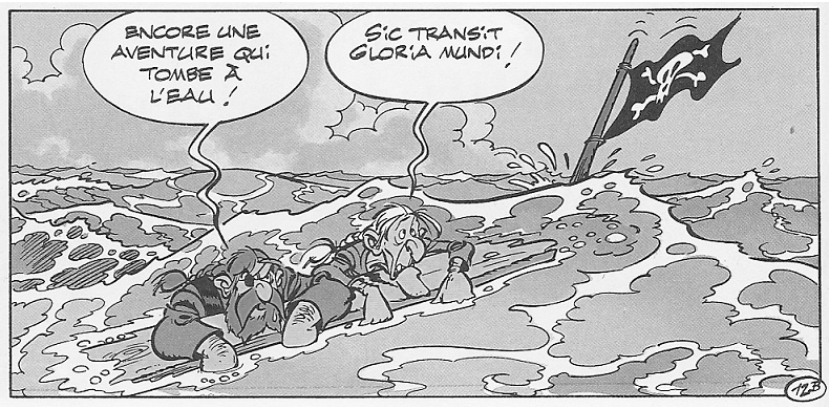

$1^{\circ}$ Balão: Mais uma

expedição que dá em água!

$2^{\circ}$ Balão: Sic transit gloria

mundi!

(Tradução apresentada na

edição brasileira de

Astérix chez Rahazade)

Figura 2: Extraído de UDERZO, A. \& GOSCINNY, R. Astérix chez Rahazade. Paris: Hachette, 1987

Nessa Figura 2, observa-se a expressão idiomática tomber à l'eau, que em francês significa "fracassar", "não conseguir algo que se deseja". Ora, através da imagem, que mostra os personagens na água, os autores evocam uma leitura literal da expressão idiomática, que seria "cair na água" (tomber/cair, à l'eau/ na água). A princípio, tal expressão seria interpretada em sua forma fixa, ou seja, o fracasso dos piratas em sua aventura. Mais tarde, porém, vemos que a imagem aponta para outra leitura possivel, a qual provoca um efeito de humor inusitado justamente por apresentar um sentido literal que não seria de imediato acionado pelo leitor.

Vale ressaltar que os personagens da Figura 2 aparecem em quase todos os volumes da série Asterix. Trata-se de um grupo de piratas que sempre tem seu navio afundado graças aos "irredutiveis gauleses"; desse modo, eles nunca têm sucesso em suas atividades de pilhagem de navios. Isso certamente justifica a fala do pirata - encore ("mais uma vez") -, fazendo referência aos outros encontros que tiveram com a dupla de guerreiros Asterix e Obelix.

No próximo item, veremos mais alguns exemplos de como a interação entre imagem e texto é explorada por Uderzo \& Goscinny em Asterix e de que maneira tal interação é tratada na tradução. Ao mesmo tempo, propomos uma análise a partir da seleção de quadrinhos em que constatamos efeitos de humor por meio da relação entre imagem e texto na obra original em francês, bem como a representação de gestos reforçados pela 
fala dos personagens. Importante assinalar que através da análise dos quadrinhos, pudemos observar e classificar cinco construções apoiadas na relação entre imagem e texto. Tais classificações podem servir como uma reflexão ou tipologia inicial sobre a complexa tarefa de traduzir HQ.

\section{As relações entre imagem e texto na tradução de histórias em quadrinhos}

Através da análise dos álbuns da série Asterix, constatamos que a relação entre imagem e texto se dá por meio de cinco processos principais: literalização, polissemização, situacionalização, enfatização e culturalização ${ }^{6}$. Esses processos foram observados e classificados tendo em vista a função que a imagem estabelece em relação ao texto, de modo a criar diversos efeitos nos quadrinhos, tais como o humor ou a aproximação com a fala cotidiana, conforme apontamos anteriormente.

\subsection{Literalização}

O processo da literalização consiste na interpretação de uma expressão verbal em seu sentido literal, em que se dá a desmontagem do sentido partilhado por uma comunidade linguística de modo a provocar um novo efeito de sentido. Apoiados na imagem, os processos de literalização evocam as duas leituras possiveis que a expressão idiomática pode ter; ou seja, a literal, que causa o feito inusitado, e a idiomática, que é reconhecida automaticamente pelos falantes da língua. Tal classificação foi elaborada por Pinto (1997), especialmente no contexto do discurso publicitário:

Os slogans também brincam, por vezes, com a "literalização" de uma lexia complexa que se baseia no mesmo efei-

6 A literalização foi definida por Pinto (1997). Já o termo enfatização surgiu a partir de Steinberg (1988) acerca dos "gestos enfáticos". Os demais processos são classificações nossas.

TradTerm, 16, 2010, p. 435-463 
to de desmontagem de um automatismo linguístico. Nestes casos, normalmente, as duas interpretações possíveis ficam disponiveis - leitura fórmula fixa vs leitura literal - sendo a imagem e o próprio conhecimento do mundo do receptor que ajudam a selecionar uma delas. (Pinto, 1997:117)

Segundo a autora, a utilização desse recurso conta, para que tenha êxito, com os conhecimentos prévios do leitor/receptor, que deve ser capaz de decodificar o jogo operado entre a imagem e o texto literalizado, caso contrário, o processo falha e a relação permanece sem sentido. Na série Asterix, destacam-se nesse tipo de relação as expressões idiomáticas, que, nos casos estudados, demonstraram compor o fenômeno mais complexo de literalização. Como ilustração, vejamos o quadrinho a seguir, que abre o álbum Astérix chez les Belges:

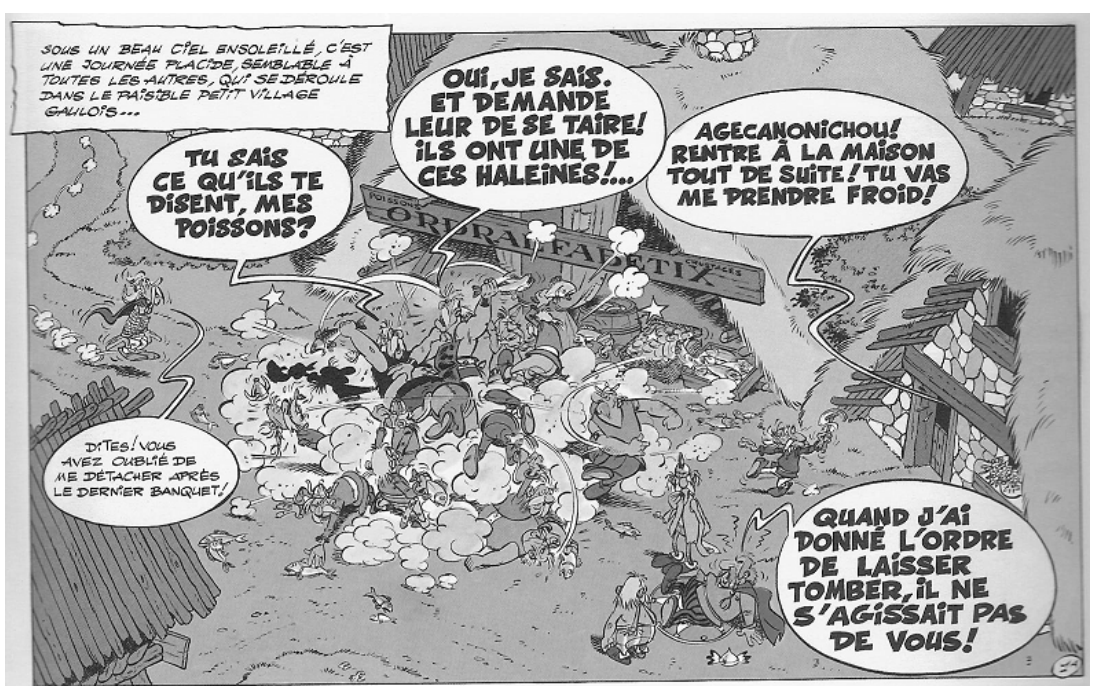

Figura 3: Extraído de UDERZO, A. \& GOSCINNY, R. Astérix chez les Belges. Paris: Hachette, 2005

No canto inferior direito da Figura 3, nota-se a literalização da expressão idiomática laisser tomber, que em francês significa "ignorar", "deixar pra lá". A imagem, por sua vez, representa o personagem caído no chão. Na relação entre o texto e a 
imagem, a expressão é interpretada em seu sentido literal ("deixar cair", laisser/deixar e tomber/cair), uma vez que os personagens que carregavam o chefe deixam-no cair; o chefe, entretanto, não se dirigia a eles, mas ao grupo que aparece brigando ferozmente no outro plano. Assim, mesmo que a ordem dada pelo chefe não apareça explicitamente e haja a remissão a uma fala anterior, já que a Figura 3 mostra o primeiro quadrinho do álbum, o leitor francófono entende o jogo entre o implícito laissez tomber como "parem com isso, não briguem mais, deixem pra lá", dirigido ao grupo, e o explícito “...ordre de laisser tomber...", dirigido aos dois personagens que carregam o chefe, depreendendo o efeito cômico que a literalização da expressão idiomática encerra.

Observemos agora o mesmo quadrinho traduzido para o português do Brasil:

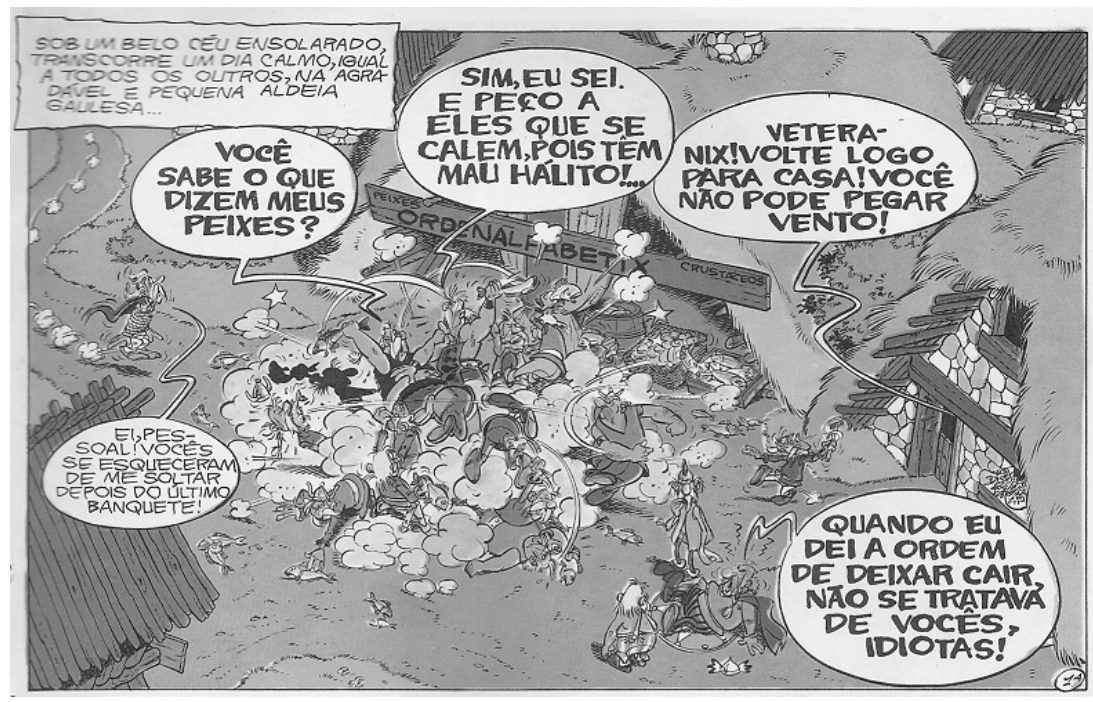

Figura 4: Extraído de UDERZO, A. \& GOSCINNY, R. Asterix entre os belgas. Rio de Janeiro: Record, 1987

Como se pode constatar na Figura 4, o tradutor brasileiro optou por traduzir literalmente a expressão idiomática francesa laisser tomber por "deixar cair", que não permite identificar o processo de literalização presente no original em francês, pois a 
leitura como forma fixa de "deixar pra lá" não é recuperada no texto traduzido.

Uma proposta de estratégia de tradução para o caso exposto nas Figuras 3 e 4 seria elencar expressões idiomáticas utilizadas no Brasil aludindo à construção presente no original em francês. Para tanto, acreditamos que expressões como "cair em si" ou "cair fora" transmitem a ideia de queda, representada através da imagem que mostra o chefe Abracurcix caído no chão; tais expressões podem, inclusive, ser utilizadas no contexto apresentado no quadrinho, que é a confusão. A expressão "cair em si”, por exemplo, indica o ato de tomar consciência sobre uma ação que, geralmente, é vista como um erro ou imprudência, o que poderia aplicar-se à confusão representada na imagem. $\mathrm{Pa}-$ ralelamente, a expressão "cair fora" indica o desejo de sair rapidamente, escapar ou fugir de algum lugar, que bem poderia acomodar-se ao possível intento do chefe Abracurcix de fugir da confusão.

Com efeito, as expressões idiomáticas extrapolam o domínio da língua e refletem elementos culturais próprios de uma determinada comunidade. Esta expressa por meio dos idiomatismos a visão que estabelece com o mundo. Partindo disso, a dificuldade de se traduzir tais construções consiste não só na relação que elas estabelecem com a cultura do país de origem, como também no contexto em que elas são apresentadas, conforme pudemos observar no caso da Figura 3, em que "deixar pra lá", solução apontada pelos dicionários bilíngues, não seria uma tradução possível graças à relação que a expressão laisser tomber estabelece com a imagem. A respeito das dificuldades da tradução de expressões idiomáticas, afirma Jorge:

O uso de uma EI [Expressão idiomática] num determinado contexto pressupõe uma construção da língua enquanto elemento social, é pois o discurso que elas ilustram. Por outro lado, o seu uso neutraliza a literalidade das palavras, incutindo sentidos cristalizados e partilhados pelos sujeitos, aumentando o grau de subjectividade, definindo as marcas idiolectais, construindo valores mais perenes a uma linguagem em constante mutação, deixando, ao longo de anos, de séculos de história, os traços de um passa-

TradTerm, 16, 2010, p. 435-463 
do actualizados no presente. Elementos de uma partilha social e sincrónica, mas também uma partilha de gerações, entre o passado e o presente, entre a língua de ontem e a lingua de hoje, as EIs reflectem o movimento, a evolução da lingua, as metáforas do passado, os desvios lexicais, sintácticos e semânticos. Estas "palavras" enriquecem a linguagem pelo seu poder criativo, pelas referências culturais, pelas histórias que encerram. (Jorge, 1997:34)

Em seu estudo, Jorge (1997) elenca três dificuldades principais referentes à interpretação de expressões idiomáticas traduzidas, tendo em vista o leitor dessas traduções:

- dificuldades de reconhecimento (a EI [Expressão idiomática] pode confundir-se com frases não idiomáticas); - dificuldades de interpretação (o sentido literal pode preceder o sentido idiomático e substituir esse);

- dificuldades de produção (o falante pode sentir dificuldade em reutilizar a expressão num contexto). (Jorge, 1997:40)

Dentre essas, a que mais se aproxima do caso mostrado nas Figuras 3 e 4 seria a "dificuldade de interpretação", pois, como a própria autora diz, "o sentido literal pode preceder o sentido idiomático e substituir esse". Desse modo, pode-se dizer que o tradutor acabou por priorizar o sentido literal da expressão idiomática em francês, omitindo o sentido idiomático, ou a leitura como forma fixa da expressão que é "deixar pra lá".

Desse modo, em contexto de tradução, nem mesmo as expressões idiomáticas escapam à variação. Como vimos anteriormente, o seu uso nas histórias em quadrinhos e em outras linguagens que trabalham com a relação entre imagem e texto não neutraliza, por um lado, a literalidade, como diz a autora, nem, por outro, deixa de jogar com a perenidade de seus valores.

\subsection{Polissemização}

Além da literalização, pudemos observar que os autores da série Asterix se valeram largamente da polissemia na relação

TradTerm, 16, 2010, p. 435-463 
entre texto e imagem para criar diversos efeitos cômicos, o que designamos de polissemização ${ }^{7}$.

Para Lopes \& Pietroforte (2003:131), palavras polissêmicas são aquelas que "possuem mais de um significado para o mesmo significante". No discurso, segundo os autores, é o contexto que determina o significado dessas palavras. Nos casos estudados, enquanto a palavra escrita aponta para um de seus significados, a imagem aponta para outro. Vejamos abaixo como a polissemização se manifesta:
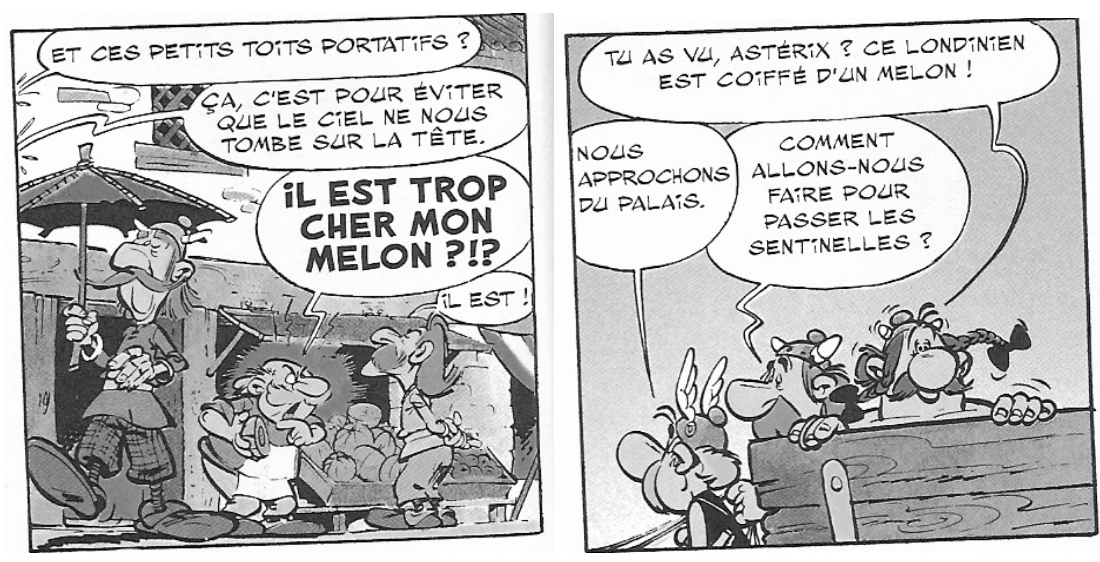

Figura 5a: Cf. UDERZO, A. \& GOSCINNY, R. Astérix chez les Bretons. Figura 5b: Idem Figura 5a

Na Figura 5a, a palavra melon (melão) está em relação direta com a imagem da fruta que está na banca e na mão do vendedor. No quadrinho seguinte (Figura 5b), a fala de Obelix alude a uma segunda acepção do vocábulo melon em francês: ao dizer "coiffé d'un melon" o personagem faz referência a um tipo de chapéu arredondado que lembra a fruta representada no quadrinho anterior. Imediatamente, as relações entre imagem e texto nos dois quadrinhos desencadeiam um efeito humorístico baseado na polissemia.

7 Cumpre ressaltar que não trataremos neste artigo das ocorrências de homonimia encontradas, tampouco discutiremos as diferenças entre polissemia e homonímia.

TRadTerm, 16, 2010, p. 435-463 
Um dos elementos complicadores da tradução desse processo é, além da presença da imagem, o fato de a polissemia se manifestar de diferentes modos nas diferentes línguas, cujos jogos semânticos são frequentemente distintos. Desse modo, o tradutor tem de lidar não só com dificuldades linguísticas para estabelecer relações similares para o seu leitor como também com o fato de, frequentemente, não poder alterar a imagem e as representações culturais que dela decorrem. Na tradução feita para o português, o tradutor escolheu a seguinte estratégia:
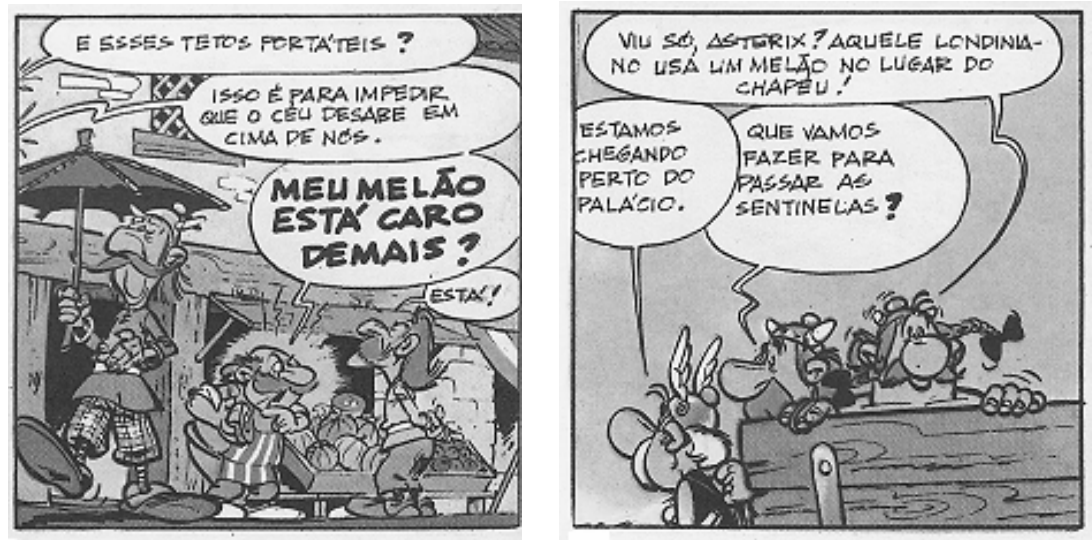

Figura 6a: Cf. UDERZO, A. \& GOSCINNY, R. Asterix entre os bretões. Rio de Janeiro: Record, 1966. Figura 6b: Idem Figura 6a

Nas figuras acima, observa-se uma tradução literal de melon por "melão", o que não reconstrói o processo de polissemização presente em francês e, consequentemente, o efeito sutil de humor do original. Para o leitor da tradução, o jogo polissêmico não aparece, uma vez que não há relação entre as palavras "melão" e "chapéu" em português brasileiro.

Uma possivel solução para o caso acima seria traduzir melon por "coco", visto que esta palavra em português faz referência à fruta e também a um tipo de chapéu. No quadrinho original colorido, os melões são verdes, assim, ao se optar pela palavra "coco", o público brasileiro não teria dificuldades em reconhecer a imagem e a relação que esta estabelece com o texto a fim de criar o efeito de humor presente no contexto original.

TradTerm, 16, 2010, p. 435-463 
Mesmo que a fruta brasileira não fosse encontrada na Europa do século V, época em que se passam as aventuras de Asterix, o que vale aqui é manter a construção apresentada em francês e o humor decorrente dela, ainda que o tradutor reproduza tal efeito por meio de anacronismos. Aliás, vale ressaltar que neste mesmo álbum, intitulado Astérix chez les Bretons (Asterix entre os Bretões), os próprios autores fazem uma alusão direta à banda inglesa The Beatles, de onde se conclui que o anacronismo faz parte do humor de Uderzo \& Goscinny.

No próximo item veremos outros exemplos de como elementos culturais e de conhecimento de mundo dos leitores são utilizados na série.

\subsection{Situacionalização}

Assim como o processo de polissemização explorado no item anterior, a situacionalização está na base de diversos jogos de palavras. Nesse processo, a situação apresentada e construída pela imagem é determinante para a compreensão dos jogos de palavras, cujas relações semânticas não são dadas de forma direta pelas palavras e imagens, mas sim pelo contexto situacional e cultural. Os casos de situacionalização podem estar ligados a palavras polissêmicas ou a expressões idiomáticas; porém, diferentemente da literalização e da polissemização, que não implicam uma referência a representações culturais fortemente estabelecidas, a situacionalização aciona elementos culturais que muitas vezes ultrapassam a relação intercultural das duas línguas envolvidas; ou seja, evocam conhecimentos intertextuais diversos no leitor. Para esclarecer a questão, vejamos os seguintes quadrinhos:

TradTerm, 16, 2010, p. 435-463 

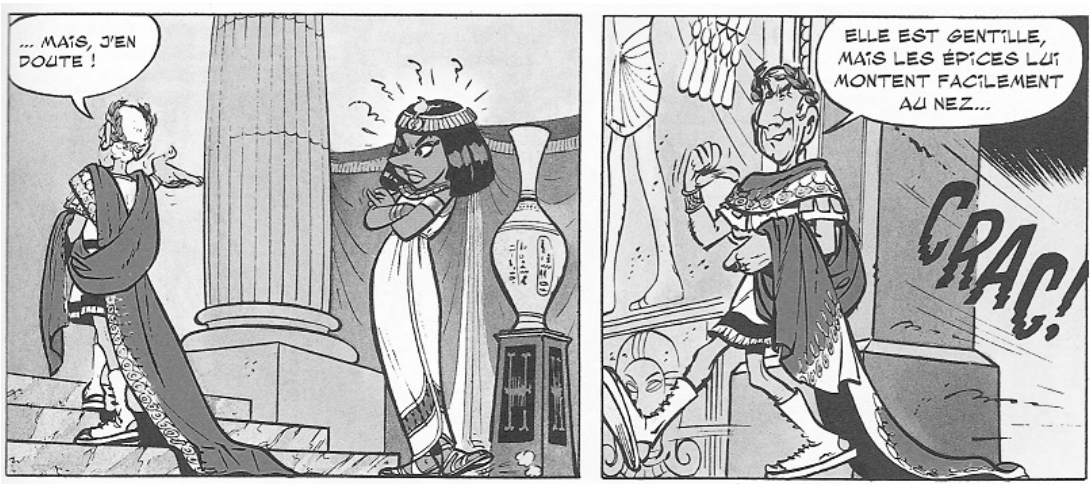

Figura 7a: Cf. UDERZO, A. \& GOSCINNY, R. Astérix et Cléopatre. Paris: Hachette, 2004.

Figura 7b : Idem Figura 7a

Na sequência acima, observa-se o processo de situacionalização marcado principalmente na palavra nez. A lexia aparece nos idiomatismos monter au nez e la moutarde lui monte au nez, em que épices (condimentos, temperos), substituindo moutarde, irritam (coçam, ardem ou, literalmente, sobem por) o nez (nariz) de alguém. Se traduzida para o português por uma expressão idiomática, teriamos "ter o pavio curto", "sair do sério" ou ainda "armar um barraco". Em 7b, o personagem Julio César diz: Les épices lui montent facilement au nez, em que a relação entre a expressão e a imagem se dá pela palavra nez, fazendo alusão ao famoso nariz da personagem Cleópatra representada no quadrinho, cujo traço de personalidade colocado em relevo é o da irritabilidade. Vejamos, agora, como o quadrinho foi traduzido para o português: 


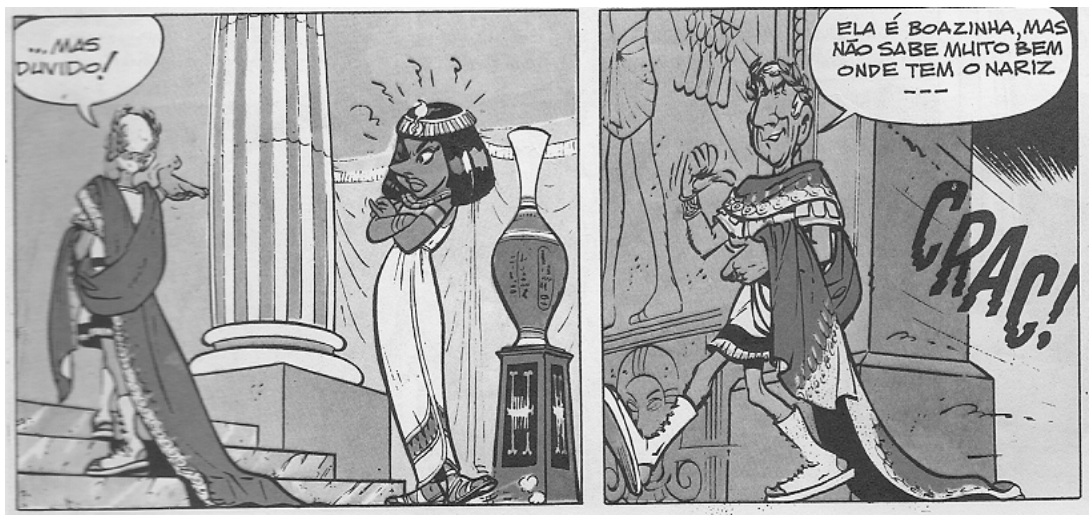

Figura 8a: Extraído deUDERZO, A. \& GOSCINNY, R. Asterix e Cleópatra. Rio de Janeiro: Record, 1985. Figura 8b: Idem Figura 8a

$\mathrm{Na}$ figura $8 \mathrm{~b}$, vê-se que o tradutor manteve a relação entre a imagem, que coloca em relevo o nariz da personagem, e o texto, para provocar o efeito cômico, já que nez aparece traduzido em português na sequência "não sabe muito bem onde tem o nariz", remetendo à expressão "não sabe muito bem onde mete o nariz/bedelho", bastante recorrente. Mesmo que preferíssemos "mete" em lugar de "tem" (não sabe muito bem onde mete o nariz), a opção do tradutor confere naturalidade ao texto e mantém o jogo presente na obra original em francês. Ainda que a irritabilidade da rainha egípcia não seja explicitamente retomada na tradução, a solução do tradutor segue na direção do temperamento explosivo de Cleópatra: "não saber onde tem o nariz" faz alusão ao fato de Cleópatra ter desafiado e contrariado o imperador romano; assim, pode-se dizer que a tradução proposta é bem sucedida na medida em que recupera o efeito presente no original, pois a relação entre imagem e texto precisa ser posta em relevo na tradução de histórias em quadrinhos.

\subsection{Enfatização}

Diferentemente dos três processos expostos anteriormente, os quais, de um modo geral, estão associados a jogos de palavras e outras subversões da língua de modo a criar efeitos de 
humor, o processo de enfatização associa-se a gestos cuja função comunicativa está associada à fala, que os reforça ou enfatiza. Desse tipo de gesto fazem parte aqueles manifestados nos dois ambientes socioculturais analisados, o francês e o brasileiro, como: os dêiticos, os quais, segundo classificação elaborada por Steinberg (1988:18), são aqueles que "apontam para algo ou alguém"; os ritualísticos, que são empregados em saudações e cerimônias; e os aprovadores e desaprovadores, que demonstram aceitação ou negação. Segundo a autora, "os dêiticos apontam para algo ou alguém, não só com o dedo, mas com todo o braço, com a cabeça, com o olhar, ou com os lábios"; além disso, "o mesmo gesto pode exercer multiplicidade de funções, bem como ter significados diferentes, dependendo do contexto" (idem, ibidem), de modo que as categorias podem variar ou se sobrepor no momento em que o ato comunicativo se manifesta.

Vale ressaltar que tanto os gestos representados quanto as falas que os acompanham encontram significação quando usados isoladamente. Falas e gestos dêiticos, ritualísticos e aprovadores ou desaprovadores podem ser, e na maioria das vezes o são na relação intercultural francófona e brasileira, independentes entre si porque constituem sistemas de comunicação distintos. O que os aproxima é o próprio ato comunicativo, que frequentemente se vale não só da língua, mas também dos gestos e demais expressões corporais.

Nesse sentido, a relação entre imagem e texto acionada a partir do processo de enfatização pode ser aproximada do que Cagnin (1975), talvez impropriamente, chama de imagem redundante, pois, segundo o autor, palavra e imagem desempenham a mesma função ou transmitem a mesma informação. Consideremos o quadrinho a seguir:

TRAdTerm, 16, 2010, p. 435-463 


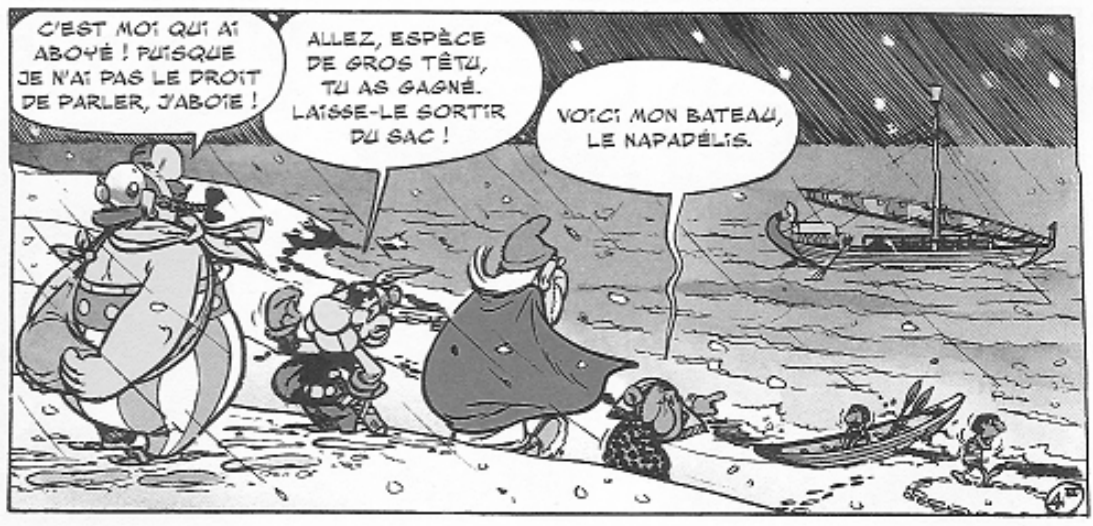

Figura 9: Extraído de UDERZO, A. \& GOSCINNY, R. Astérix et Cléopatre. Paris: Hachette, 2004

No caso da Figura 9, o personagem aponta com o dedo na direção do barco e ao mesmo tempo diz voici. Trata-se de um gesto dêitico, que indica uma direção. A tradução deu facilmente conta da enfatização, conforme ilustra a figura seguinte:

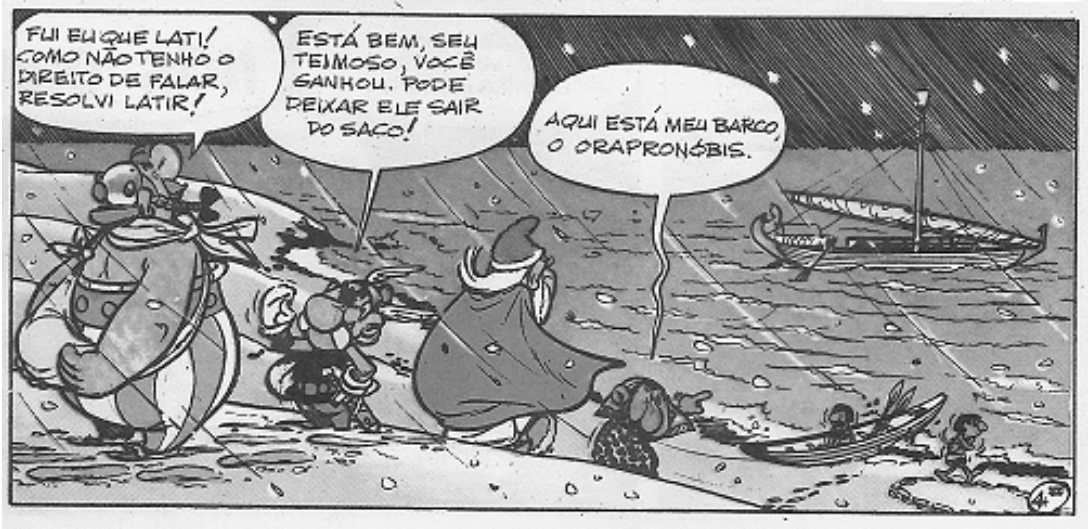

Figura 10: Extraído de UDERZO, A. \& GOSCINNY, R. Asterix e Cleópatra. Rio de Janeiro: Record, 1985

Nas Figuras 9 e 10 acima, o gesto e a fala estabelecem uma relação de complementaridade enfática ou de enfatização, pois o gesto de apontar com o dedo para uma direção ou a fala do personagem poderia aparecer independentemente, sem equí- 
vocos de interpretação, uma vez que os gestos inseridos nessa categoria se manifestam tanto no contexto comunicativo francês como no brasileiro, de modo que o conceito de imagem redundante de Cagnin (1975) pode ser aplicado somente a esses casos, graças à "neutralidade" dos gestos. Contudo, não é possível classificar como imagem redundante todos os gestos enfatizados pela fala, principalmente no caso da tradução, que considera dois universos linguísticos e comunicativos distintos, como veremos no próximo item.

\subsection{Culturalização}

Paralelamente ao processo de enfatização, notaram-se casos, em nossa pesquisa de representações de gestos, que não existiam ou não faziam sentido dentro dos contextos comunicativos do Brasil. De um lado, há, no original em francês, o estabelecimento de relações que demandam, por parte do leitor francófono, o reconhecimento de elementos culturais específicos para construir os sentidos do quadrinho; de outro, esses elementos aparecem na tradução reivindicando ao leitor brasileiro um conhecimento cultural que não possui. A título de exemplificação, observemos o quadrinho a seguir:

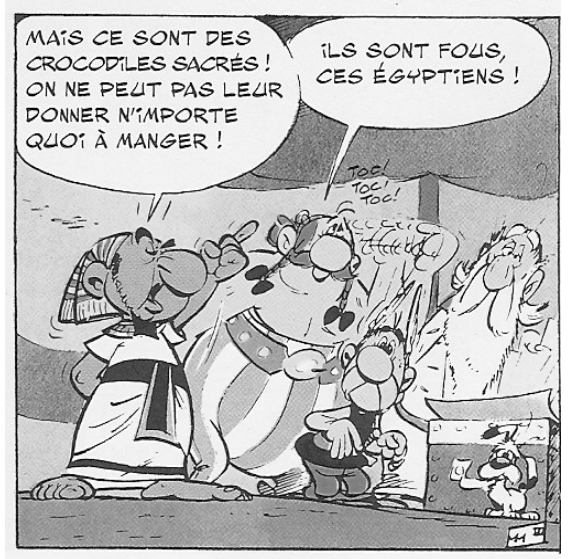

Figura 11: Extraído de UDERZO, A. \& GOSCINNY, R. Astérix et Cléopatre. Paris: Hachette, 2004

TradTerm, 16, 2010, p. 435-463 
Na Figura 11, o personagem faz um gesto que, na cultura francesa, significa que o outro não bate bem ou tem um parafuso a menos. Batendo com o dedo indicador na têmpora, gesto esse reforçado pela fala Ils sont fous, ces égyptiens, que remete ao bordão da série Ils sont fous, ces romains, o personagem remete a um sentido fortemente marcado culturalmente, uma vez que esse sentido só encontra correspondente na cultura de chegada por um outro gesto, realizado também pelo dedo indicador mas que faz, na cultura brasileira, movimentos circulares na região da orelha. Vejamos a tradução:

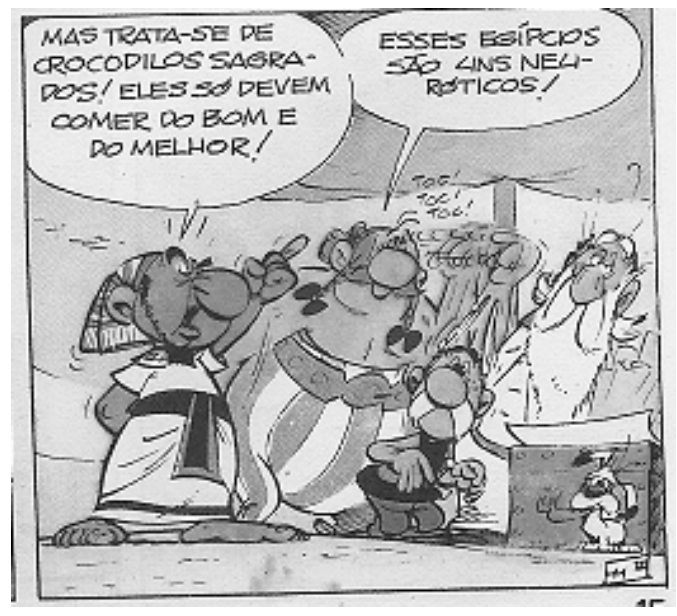

Figura 12: Extraído de UDERZO, A. \& GOSCINNY, R. Asterix e Cleópatra. Rio de Janeiro: Record, 1985

Percebe-se na figura 12 que a imagem não foi modificada. Porém, como esse gesto é frequentemente acompanhado dessa fala nos álbuns da série, o texto complementa o gesto, que, vale notar, é muito semelhante ao nosso. Entretanto, considere-se o seguinte quadrinho: 


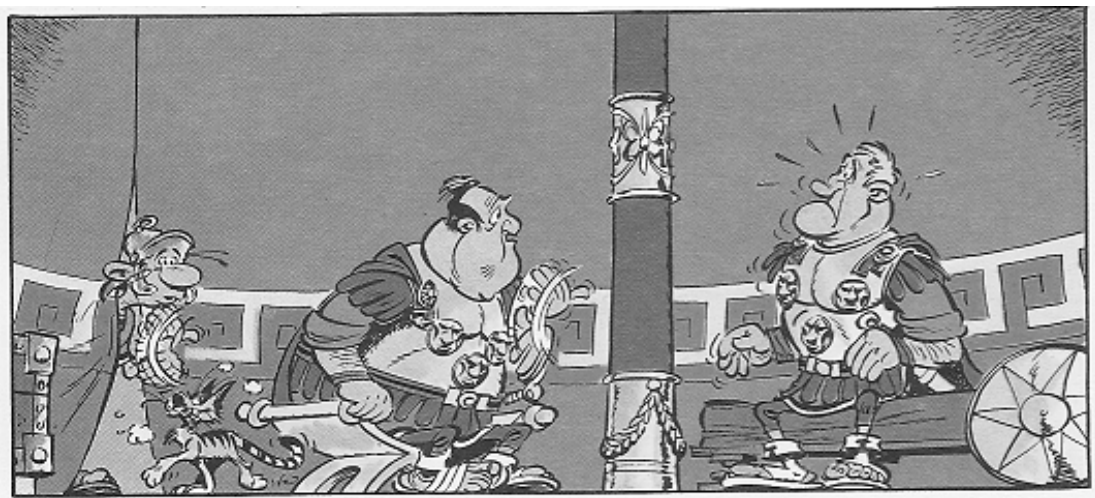

Figura 13: Extraído de UDERZO, A. \& GOSCINNY, R. Astérix - La Rose et le Glaive. Paris: Hachette, 1991

Na Figura 13, os personagens fazem um gesto com a mão esquerda que, na cultura francesa, significa algo em excesso. No contexto em que aparece esse quadrinho, os personagens estavam discutindo sobre a coragem do povo gaulês - do qual os personagens principais Asterix e Obelix fazem parte - e o quão terrivel eles poderiam ser com seus inimigos romanos. Conforme apontado por Eguti (2001), muitas vezes os gestos figuram na comunicação sem estarem acompanhados por uma fala ou por um som, como acontece na figura anterior. Como não há uma fala no quadrinho, o leitor brasileiro fica impossibilitado de compreender o significado desse gesto. Trata-se, em suma, de um gesto cultural e que reflete uma particularidade do processo de comunicação em língua francesa, estabelecendo uma ligação com o contexto social em que a obra foi concebida. Nesse caso, a diferença entre culturas oferece uma barreira na interpretação não solucionada por meio da tradução, uma vez que se tratam de dois contextos socioculturias distintos.

A respeito do contexto nas HQs, Cagnin (1975) afirma que ele está vinculado à capacidade de relacionar as sensações recebidas com os dados que envolvem ou antecedem a comunicação visual; desse modo, configura-se o contexto cultural extraicônico, que corresponde a elementos dados pelo senso comum de um determinado ambiente sociocultural não explicitados na obra. Partindo disso, constata-se a dificuldade de se compreender his- 
tórias em quadrinhos de autores estrangeiros cujos personagens agem de forma diferente da nossa realidade, refletindo aquela cultura. Ainda segundo o autor, os gestos e as expressões corporais constituem um artifício amplamente utilizado pelos cartunistas contemporâneos, visto a sua função altamente representativa e a sua relação com a fala cotidiana; assim, os gestos atribuem "maior função narrativa à imagem" (Cagnin 1975:110).

\section{Considerações finais}

Através desta breve análise da tradução de histórias em quadrinhos, pudemos elencar e classificar cinco processos pelos quais as relações entre imagem e texto se manifestam e a maneira como elas se colocam no processo tradutório. Vimos que os processos de literalização, polissemização e situacionalização se constróem principalmente a partir de jogos de palavras apoiados na imagem, fator que dificulta o processo de tradução; ao passo que os processos de enfatização e culturalização estão mais ligados aos gestos e à reprodução de contextos de comunicação entre os falantes de uma determinada comunidade linguística, que podem não ocorrer na língua/cultura do país de chegada.

No caso específico do fenômeno que aqui chamamos de literalização e a sua conceituação no campo das histórias em quadrinhos, não encontramos bibliografia tratando o assunto de forma específica dentro dessa linguagem, pois, conforme já mencionamos, Pinto (1997) aborda a questão da literalização, mas o faz no âmbito do discurso publicitário. Por outro lado, Fresnault-Deruelle (1980), em seu artigo O espaço interpessoal dos comics, tece breve comentário sobre a tendência de os quadrinhos atuais representarem, através de imagens, metáforas e algumas expressões idiomáticas, sem, contudo, definir tal processo:

O olho escuta, a mão ouve, a orelha vê, as metáforas poéticas são, de repente, tomadas ao pé da letra e convertidas em imagens. A engenhosidade dos desenhistas-rotei-

TradTerm, 16, 2010, p. 435-463 
ristas chega até mesmo a cair no surrealismo. (FresnaultDeruelle, 1980:145)

O pesquisador também menciona, em nota de rodapé, o fato de esse uso da ilustração em relação às expressões idiomáticas e às metáforas verbais constituírem procedimentos estéticos utilizados pelos quadrinhistas de forma a desencadear um efeito cômico: "de um modo geral, a HQ cada vez mais parece dar expressão gráfica às metáforas verbais. Expressões como 'raser le mur' ou 'manger des chaussons aux pommes' constituem assim a motivação cômica" (Fresnault-Deruelle, 1980:145).

Considerando, por fim, a enorme quantidade de HQ traduzidas em diversas partes do mundo e, particularmente, no Brasil, nosso estudo buscou lançar uma investigação inicial sobre a tradução de quadrinhos, expondo problemas e características específicas da tradução dessa mídia tão peculiar que vem se constituindo de forma bastante sólida, principalmente nas últimas décadas.

\section{Referências bibliográficas}

AUBERT, F. H. (1994) As (in)fidelidades da tradução. Campinas: Editora da Unicamp.

BARTHES. R. (1990) O óbvio e o obtuso. Rio de Janeiro: Nova Fronteira. CAGNIN, A. L. (1975) Os quadrinhos. São Paulo: Ática.

EGUTI, C. A. (2001) A representatividade da oralidade nas histórias em quadrinhos. Dissertação de Mestrado. São Paulo: Universidade de São Paulo.

EISNER, W. (2005) Narrativas gráficas. São Paulo: Devir.

FRESNAULT-DERUELLE, P. (1972) La bande dessinée: l'univers et les techniques de quelques "comics" d'expression française. Paris: Hachette. (1980) O espaço interpessoal dos comics. In: HELBO, A. (org.). Semiologia da representação: teatro, televisão, histórias em quadrinhos. São Paulo: Cultrix, pp. 125-146.

JORGE, G. (1997) Reflexões em torno da tradutologia das construções fraseológicas na perspectiva interlínguas. Revista Polifonia, Lisboa: Edições Colibri, $n^{\circ}$ 1, pp. 33-43. (Disponível em http://www.fl.ul.pt/ unil/pol1/pol1_txt4.pdf)

TradTerm, 16, 2010, p. 435-463 
LOPES, I. C.; PIETROFORTE, A. V. S. (2003) A semântica lexical. In: FIORIN, J. L. (org.) Introdução à lingüistica II: princípios de análise. São Paulo: Contexto, pp. 111-135.

PIETROFORTE, A. V. (2004) Semiótica visual: os percursos do olhar. São Paulo: Contexto.

PINTO, A.G. (1997) Publicidade: um discurso de sedução. Porto: Porto Editora, pp. 117-118.

SOUZA, L. S. M. (1997) O humor é coisa séria - Tradução de tiras: exemplificando com Frank e Ernest. Dissertação de Mestrado. São Paulo: Universidade de São Paulo.

STEINBERG, M. (1988) Os elementos não-verbais da conversação. São Paulo: Atual Editora.

PEREIRA, N. (2008) Traduzindo com imagens: a imagem como reescritura, a ilustração como tradução. Tese de Doutorado. São Paulo: Universidade de São Paulo.

WOLK, D. (2007) Reading comics: how graphic novels work and what they mean. Philadelphia: Capo Press. 